\title{
EVALUATION OF THE LITURGICAL ROLE OF MINOR ORDERS IN THE EASTERN-WESTERN CHURCHES
}

\author{
Pr. dr. Lucian Mihăiță FILIP \\ Facultatea de Teologie Ortodoxă „Dumitru Stăniloae” din Iași \\ https://doi.org/10.47433/tv.xcvn9-12.69
}

\begin{abstract}
With its origin in the New Testament, Ordination has always been seen by the majority of Churches as one of the seven Sacraments. As the time passed the specific forms, roles, rites, and rules that established the validity of the Sacrament of Ordination adapted at the same time with the Church. The roles of the clergy suffered many changes either by exchanging some of the roles between themselves or by eliminating some of these roles and creating new ones. We observed that the functions and duties of the minor orders have been in a continuous change due to the dynamic character and the needs of the Church. Some minor orders either developed into new ones or absorbed others.
\end{abstract}

Keywords: minor order, major orders, liturgy, Eastern Church, Western Church, doorkeeper, reader, exorcist, widow, virgin, subdeacon, deaconess, acolyte.

The present Christian ministries were created and developed along with the Church ${ }^{1}$ and the hierarchical nomenclature is varied by using all sort of the terms for grouping the Christian ministries (e.g. The Twelve, Apostles, The Seventy, Orders etc.). Historically, one can speak about two categories of orders. The first one is that of the major orders - bishop, presbyter/priest and deacon. They are all mentioned in the New Testament though there is no common agreement on how they are related one with the other ${ }^{2}$. The second order is that of the minor orders. "Minor orders" is a term that started to be used in the medieval West in order to distinguish a group of clergies which included the order of doorkeeper (porter

${ }^{1}$ Paul F. Bradshaw, Rites of Ordination: Their History and Theology, SPCK, London, 2014, p. 1.

${ }^{2}$ Kenneth Stevenson, The first rites: Worship in the Early Church, The Liturgical Press, Collegeville, 1989, p. 69. 
or ostarius), reader (lector), exorcist, widow, virgin, subdeacon (hypodeacon), deaconess and acolyte from the one called „major orders". If in the case of the major orders there is no full agreement about their relation, the situation is no different in respect with the minor orders. The candidates were not elected by the community but by the bishop and for this reason there was no need for the community to have prayers done for the candidates as in the case of major orders ${ }^{3}$. Thus, being in a continuous shaping and constant adaptation the Church cannot speak about a clear-cut terminology of the clergy and a systematic description of their liturgical roles. If in terms of the major orders we can speak about them reaching their final form around the end of the $1^{\text {st }}$ century, in the case of the minor orders we have to wait until the $3^{\text {rd }}$ century to be able to speak about their approximate contour. Thus, in this paper I will discuss and evaluate the Liturgical roles of the minor orders both in the Eastern and Western Church. Having to deal with two broad traditions, respectively two Churches, I will make only one exposition of the argument and where to case will be, I will note what are the differences between the Western and Eastern Church.

\section{The development of the role of the minor orders}

In the first section of my paper I will present how the minor orders were created, what ritual of consecration was involved, and starting from this I will extract information about the roles they had in the early stages of this creation process.

The first express mention of the order of reader is found in St. Justin (Apol. I. 67.3). The reader had an independent origin though some argue that it represents the continuation of the prophet from the apostolic age $\mathrm{e}^{4}$. The rite for appointing the reader consisted in handing him a book by the bishop from which he would read ${ }^{5}$. From the Canons of Hippolytus (336-340) we learn that the reader received the Holy Gospel. This implies that reading from the gospel during services was at some point permitted also to the reader ${ }^{6}$. If

${ }^{3}$ Paul F. Bradshaw, Ordination rites of the Ancient Churches of East and West, Pueblo Publishing Company, New York, 1990, p. 93.

${ }^{4}$ A.R. Whitham, Holy Orders, Longmans, London, 1903, p. 277.

${ }^{5}$ The Treatise on The Apostolic Tradition of St Hippolytus of Rome, edited by Gregory Dix, Alban Press, London, 1992, p. 21.

${ }^{6}$ The canons of Hippolytus, edited by P. Bradshaw and translated by C. Bebawi, Grove, Bramcote, 1987, p. 15. 
indeed, he was allowed to read from the Holy Gospel, this custom did not happen for a long time because soon, only the deacon was allowed to do that, apart from the bishop and the priest. Apostolic Constitutions (375-380) mentions a prayer for the invocation of the Holy Spirit, the imposition of the hands but not the word „ordination" for the reader ${ }^{7}$. Testamentum Domini ( $5^{\text {th }}$ century) resembles very much the Apostolic Tradition, because it mentions only the tradition of handing the book and the prayer and states that no laying of the hands should be made. At the end of the bishop's prayer the book states that the priest should respond three times "So be it" and all this ritual should be done in the first day of the week ${ }^{8}$. In the invocation prayer the "prophetic Spirit" is invoked and asked to instruct and grant the reader the completion of the work entrusted ${ }^{9}$. In this way he is compared with Ezra who read the law of God to the people. Testamentum Domini brings something new by listing some of the features of a future reader: „pure, gentle, humble, well-tested, skilled and learned, mindful, vigilant" in order to be suitable for a higher rank ${ }^{10}$. Accordingly, Bradshaw argues that there is no evidence for a very important liturgical role of the reader in Church at this time, because ultimately the prayer ends „by seeking the candidate's ultimate promotion to a higher order"11. Some sources say that he might even deliver a homily ${ }^{12}$. Therefore, the reader was in charge of the lesson which formed part of the liturgy both from the Old Testament (i.e. writings of the prophets) and from the New Testament (i.e. the memoirs of the Apostles) which shows that it fulfilled the ministry of teaching and of the word. Although the reader had an independent origin its role did not have an independent development. In the period that followed the Early Church, the role of the reader lost some of its importance due to the reduction of lessons during Mass at only two, that could be very well read by the subdeacon or another order.

\footnotetext{
${ }^{7}$ Paul F. Bradshaw, Ordination rites..., p. 116.
}

${ }^{8}$ The Testamentum Domini: a text for students, with introduction, translation, and notes, ed. by Grant Sperry-White, in Alcuin/Grow Liturgical Study 19, Nottingham: Grove books, Bramcote, 1991, p. 45.

${ }^{9}$ Paul F. Bradshaw, Ordination rites..., p. 116.

${ }^{10}$ The Testamentum Domini..., p. 45.

${ }^{11}$ Paul F. Bradshaw, Ordination rites..., p. 95.

${ }^{12}$ J.G. Davies, Deacons, Deaconesses and the Minor Orders in the Patristic Period, in „The Journal of Ecclesiastical History”, vol. 14, 1963, p. 11. 
Mainly, in the Eastern but also in the Western Church, this order extended to psalmistae (the person in charge with singing the psalmic elements between the Epistle and the Gospel) and later on to cantores. Today, once appointed, the reader has the liturgical role of reading the lesson from the Scripture, with the exception of the Gospel, to recite the psalm between the readings, and to direct the singing and the participation of the faithful ${ }^{13}$. Its functions can be assigned to women or laymen. In the Church of England, with a history dating from 1866, the reader is a lay person licensed to conduct the religious services such as reading the Morning and Evening Prayer or the Litany, preaching, and distributing the Bread and Wine at the Eucharist; from 1969 women have been eligible for this office ${ }^{14}$.

The first evidence for the order of the subdeacon is found in a letter of Pope Cornelius to Fabius of Antioch (251) $)^{15}$. In the Apostolic Tradition, the rite for appointing the subdeacon consisted in a nomination to the office and no laying of hands ${ }^{16}$. However, as in the case of the reader, in Apostolic Constitutions the same prayer for the invocation of the Holy Spirit and the imposition of hands are prescribed; nevertheless, a new element is added - it mentions the word ordination whereas in the case of deaconess and reader the term does not appear ${ }^{17}$. The same word is also used in the text from Testamentum Domini where it is added that the ordination is to be made on a Sunday where the bishop "prays over him" ${ }^{18}$. In the ordination prayer from the Apostolic Constitutions the subdeacon is compared with temple-keepers who were guarding the vessels and the Holy Spirit it is being invoked and asked so that he may worthily handle the liturgical vessels. Another role was to assist the deacon and be his subordinate and also to be "alert on the bishop's behalf" or carrying the bishop's letters. In Testamentum Domini it is emphasized more the moral aspect of the candidate.

\footnotetext{
${ }^{13}$ T.J. Riley and J.A. Gurrieri, eds., Lector, in „New Catholic Encyclopedia”, $2^{\text {nd }}$ edition, 8, Thomson Gale, USA, 2003, p. 441.

${ }^{14}$ Reader, in ", The Oxford Dictionary of the Christian Church", edited by F.L. Cross, Oxford University Press, New York, 1997, p. 1370.

${ }^{15}$ Eusebius, The History of the Church, translated by G.A. Williamson, Penguin Books, London; New York, c1989, p. 216.

${ }^{16}$ The Treatise on The Apostolic Tradition..., p. 22.

${ }^{17}$ Paul F. Bradshaw, Ordination rites..., p. 116.

${ }^{18}$ The Testamentum Domini, p. 44.
} 
As opposed to the deacon, he was not allowed in the altar, to touch the vessels during communion, administer the chalice or wear a stole and he stayed at the doors of the church. Therefore, the liturgical role of the subdeacon was to take care of the liturgical vessels before and after communion but not during it and to be a helper of the deacon and the bishop. In the $6^{\text {th }}$ century, evidence show that the ritual of ordination to the subdeacon office consisted in the delivery of an empty chalice, a paten, and the book of Epistles while in another evidence dating from the $8^{\text {th }}$ century we find the inclusion of an oath according to which the candidate pledged he did not commit any crime incompatible with the order ${ }^{19}$. In the Western Church the order of the subdeacon became recognised to be one of the major orders imposing celibacy and the recitation of the Breviary. This happened after the $12^{\text {th }}$ century and lead to a rich development of order's liturgical role ${ }^{20}$. The purpose was to give more dignity to the order with the effect to become very similar with that of the major orders. In $5^{\text {th }}$ century the order got another two features - the admonition to observe celibacy and the condition for the candidate to be over 21 years old ${ }^{21}$. His liturgical duties became to assist in the Offertory by preparing the bread, the wine, the vessels, removing the vessels after Communion and to chant the Epistle and in the Middle Ages it is also seen as helping the deacons in vesting the Pope ${ }^{22}$. In the Church of England, it was given up in $16^{\text {th }}$ century though recently has been restored in certain Anglican missionary dioceses. Today, the Roman Catholic does not use anymore the order of subdeacon after Pope Paul VI abolished it in $1972^{23}$. All its liturgical duties have been assigned to the reader and acolyte. In the Eastern Church the subdeacon was not allowed to marry after ordination but he could be ordained if he was already married ${ }^{24}$.

${ }^{19}$ W.J. O'shea and J.D. Shaughnessy, eds., Ordinations in the Roman Rite, in „New Catholic Encyclopedia”, $2^{\text {nd }}$ edition, 10, Thomson Gale, USA, 2003, p. 639.

${ }^{20}$ Ibidem, p. 639.

${ }^{21}$ Subdeacon, in ", The Oxford Dictionary of the Christian Church", ed. by F.L. Cross, Oxford University Press, New York, 1997, p. 1551.

${ }^{22}$ Roger E. Reynolds, Clerics in the Early Middle Ages: hierarchy and image, Ashgate, Aldershot,1999, p. 6.

${ }^{23}$ T.J. Riley, ed., Subdeacon, in "New Catholic Encyclopedia”, $2^{\text {nd }}$ edition, 13, Thomson Gale, USA, 2003, p. 564.

${ }^{24}$ Paul F. Bradshaw, Rites of Ordination..., p. 134. 
The order was always regarded as one of the minor ones. Both in the Eastern and the Western Church it was „regarded as a sacramental than a true Sacrament" ${ }^{\prime 25}$.

The order of the acolyte was first mentioned by Pope Cornelius $^{26}$ and arose from a division of the diaconal duties ${ }^{27}$. Same as in the case of the subdeacon, the acolyte had the liturgical role of assisting the bishop/priest and the deacon during the liturgical celebrations. Most of his duties were similar to those of the subdeacon, together being the assistants of the major orders. The acolyte became a standard order only at the end of the $11^{\text {th }}$ century ${ }^{28}$. As we previously saw, originally, the order of the subdeacon and that of the acolyte resembled very much but in time the latter lost its importance whereas the former gained more and more liturgical functions. The acolyte vested in chasuble and stole and was ordained during Mass. He received the sacculum from the Pope in which he will carry the Communion to those absent and present the consecrated bread to the priest for fraction. After that, followed the blessing that was said by the Pope over him ${ }^{29}$. Its liturgical role is to carry liturgical objects varying from candlesticks to books either during services or outside them ${ }^{30}$. He ensures that the altar is dressed, the bread and the wine are prepared and the liturgical vessels and the books are in their place. Today, the acolyte is also called sacristan and has the same role of aiding the deacon and ministering the priest. The Roman Catholic Church also sees this order as transitional before receiving the order of a deacon. In the Roman Catholic Church, from the $9^{\text {th }}$ century until 1992 the admission to this order was permitted only to the men. But from 1992 its duties have been permitted also to women ${ }^{31}$. The duties of the acolyte concerning the preparation of Gifts before liturgical celebrations, the distribution of the Communion, the management of some extraordinary duties or any of such duties prove that the role of the acolyte is an auxiliary but necessary one in the sacramental life of the Church.

${ }^{25}$ Subdeacon..., p. 1551.

${ }^{26}$ Eusebius, The History of the Church, p. 216.

${ }^{27}$ T.J. Riley and J.A. Gurrieri, eds., Acolyte..., p. 98.

${ }^{28}$ Paul F. Bradshaw, Rites of Ordination..., p. 137.

${ }^{29}$ W.J. O'shea, Ordinations in the Roman Rite..., p. 639.

${ }^{30}$ Roger E. Reynolds, Clerics in the Early..., p. 6.

${ }^{31}$ T.J. Riley, Acolyte..., p. 98. 
The reason why this order was placed among the minor orders is that ", as an order instituted by the Church, it was not considered a Sacrament, but a sacramental participating in the order of the deacon" ${ }^{32}$. In the Eastern Church the liturgical role of the acolyte is fulfilled by the subdeacon.

The doorkeeper is another order that developed from the functions of the deacon and became necessary when special church buildings started to be used for worship. In the Christian literature, the doorkeeper was first mentioned in the third century in one of the Pope Cornelius'letters ${ }^{33}$. The ordination rite consisted in the presentation of keys together with a formula after which the candidate had to open and close the doors of the church and ring the bells $^{34}$. The doorkeeper's main liturgical role was to guard the doors of the church. He had to help evacuate those who were not authorised to participate at the second part of the Liturgy and keep them out of the church ${ }^{35}$. Thus, his liturgical role was an organisational one. Having less and less importance, in the $9^{\text {th }}$ century, both in the Eastern and Western Church the doorkeeper either became something related to a verger taking care of the cleaning and lighting of the Church ${ }^{36}$ or received the duty of ringing the bells and assist the preacher $^{37}$. His role was never regarded as being a sacramental one. As in the case of the subdeacon, in Roman Catholic Church, the order of the doorkeeper was eliminated in 1972 and its assignments were placed among those of the two approved ministries acolyte and reader ${ }^{38}$.

The first mention of the order of exorcist is in Pope Cornelius' letter, too $^{39}$. Given the increasing number of Christians the ministers needed more help in dealing with their worship needs. The exorcist took both from the duties of the priest and from those of the deacon. The exorcist had in his responsibility the catechumens who had to be exorcised before baptism and the energumens on

\footnotetext{
${ }^{32}$ Ibidem, p. 98.

${ }^{33}$ Eusebius, The History of the Church..., p. 216.

${ }^{34}$ T.J. Riley, ed., Porter..., p. 639.

${ }^{35}$ Ibidem, p. 639.

${ }^{36}$ J.G. Davies, Deacons, Deaconesses..., p. 14.

${ }^{37}$ T.J. Riley, ed., Porter..., p. 639.

${ }^{38}$ Minor orders..., p. 1090.

${ }^{39}$ Eusebius, The History of the Church, p. 216.
} 
whom they were imposing the hand to heal from the evil spirits. Part of his role was also to visit and take care of them. Therefore, the exorcist had both a liturgical and a pastoral role. The liturgical one was taken from the priest and the pastoral one from the deacon. In the Middle Ages, one could become an exorcist only by the agreement of the Pope. In the Eastern Church the liturgical role of the exorcist was transferred to the priest. The order maintained a distinct status from the priest only in the Western Church.

We read in the Apostolic Tradition ${ }^{40}$ about the widow that she is appointed and not ordained. She is to be tested for a long time before being placed among the others and her hands are not be laid because she does not "offer the offering". The Apostolic Tradition mentions that the single role that a widow has is to pray ${ }^{41}$ but other sources name besides this that of visiting the sick, laying hands upon them and praying with them ${ }^{42}$. Didascalia asks them to make intercessions and forbids them from baptizing and teaching. From these evidence results that the order of widows had a supplicatory liturgical role.

The second minor order of women and very similar to that of the widow is the order of virgins. What appoints a virgin to its order is her choice and not laying of the hands ${ }^{43}$. She is ordained at the entrance of the altar while she is praying ${ }^{44}$. Same as the order of widows, the only liturgical role of the virgin was to pray.

Though there is much to debate over this subject, the deaconess first appears in the Scriptures at Romans 16:1 and 1 Timothy 3:2. The first mention in the Christian literature is in the Pliny epistle to Trajan from 112 and it becomes a fully performing order around A.D. $230^{45}$. The deaconess is ordained by the bishop who laid his hands on her and invoked the Holy Spirit in the presence of the presbytery and of deacons and deaconesses ${ }^{46}$. There is much evidence that the deaconess was chosen from the widows ${ }^{47}$. The order

\footnotetext{
${ }^{40}$ The Treatise on The Apostolic Tradition..., p. 20.

${ }^{41}$ Ibidem, p. 20.

${ }^{42}$ J.G. Davies, Deacons, Deaconesses..., p. 5.

${ }^{43}$ The Treatise on The Apostolic Tradition..., p. 21.

${ }^{44}$ The Testamentum Domini..., p. 44.

${ }^{45}$ J.G. Davies, Deacons, Deaconesses..., pp. 2-4.

${ }^{46}$ Paul F. Bradshaw, Ordination rites of..., p. 116.

${ }^{47}$ J.G. Davies, Deacons, Deaconesses..., p. 5.
} 
of deaconess had to perform the duties that a deacon was unable to do - visiting the heathen women in their homes and anointing the bodies of female baptismal candidates ${ }^{48}$ and also some of them were related to the liturgical assembly - supervising the admission and setting of women. She is also the intermediary between women and bishop but has no functions regarding the Communion and the altar ${ }^{49}$. In the Testamentum Domini the deaconess has a subordinated role to the widow and is seen to have less importance, not allowing a deaconess to receive communion together with the major orders as a widow in this book would usually do. Therefore, the deaconess fulfilled the tasks that the deacons could not and helped in organising the community during Mass. In the Western Church the order of the deaconess started to be known only after the $5^{\text {th }}$ century and Rome accepted it only towards the $8^{\text {th }}$ century ${ }^{50}$. In the Eastern Church this order ceased to exist around the $12^{\text {th }}$ century.

\section{Evaluation of the role of the minor orders}

The development of the minor orders was not the same in all the parts of the Christian world. We see that, in the $4^{\text {th }}$ century, the Western Church already established its minor orders whereas for the Eastern Church we will have to wait until the $12^{\text {th }}$ century for the same thing to happen. In the $12^{\text {th }}$ century, Peter Lombard classified the minor orders as ecclesiastical degrees and called them clerics. He affirmed that „in the sacrament of the sevenfold Spirit there are seven ecclesiastical degrees, namely, doorkeeper, lector, exorcist, acolyte, subdeacon, deacon, priest; however, all of them are called clerics, that is, those chosen by $\operatorname{lot}^{\prime \prime 51}$. If the liturgical roles of the major orders have not been able to remain unchanged, nonetheless that of the minor orders did. Since nowadays the Church is not merely repeating the tradition of the Early Church but it is also adapting to the believer's needs, the minor orders took new

\footnotetext{
${ }^{48}$ Paul F. Bradshaw, Ordination rites..., p. 116.

${ }^{49}$ J.G. Davies, Deacons, Deaconesses..., pp. 2-3.

${ }^{50}$ J.G. Davies, Deacons, Deaconesses..., pp. 4 and 6.

${ }^{51}$ Peter Lombard, Distinction XXIV, in „Sacraments and Worship: Key readings in the history and theology of Christian worship from the New Testament to the present", edited by Maxwell E. Johnson, SPCK, London, 2012, p. 8.
} 
forms and roles, lost or gained importance, and fought to exist. For example, the major order of the deacon extended into four minor orders: deaconess, subdeacon, doorkeeper and acolyte. One reason was that the Church was growing very fast increasing its congregations and the deacons could not fully perform their duties. As David argues, ,the increase in the number of Christians which required either a proportional increase in the number of deacons or the authorisation of other persons to perform certain of the deacon's duties" ${ }^{\prime 52}$.

This is the reason why some scholarship saw the minor orders enclosed implicitly within the deaconate. The deacon kept his sacramental duties and shared some of his organisational and social obligations. The women needed a special ministry only for them. Another reason was that in Acts 6 the number of deacons was limited to seven and in large Christian centres like Rome this number was insufficient and needed additional help ${ }^{53}$. But even this measure was not sufficient and that is how it was brought supplementary help, that of the acolytes. Nonetheless, the diaconate not only gave birth to some of the minor orders but it also absorbed duties of the minor orders. In many instances the deaconate absorbed the functions of the lectorate to read the lessons during Liturgy.

The minor orders did not have only liturgical role but also pastoral roles, sometimes being very hard to make a difference between them. The minor orders were able to acquire new roles because "they were not directly associated with the ministerial functions at the altar" ${ }^{\prime \prime 4}$. One example is that of the exorcist that had both a liturgical role and functioned as a pastoral assistant. Therefore, as Bradshaw stated, the minor orders had „minor liturgical functions ${ }^{\prime \prime 5}$. Today is recognised that the theology of orders has its roots planted in the theology of the Church and the authority of the orders is given only by a relation with the context of mission in the community ${ }^{56}$. Outside this context any order loses its meaning. In this way, the minor orders always represented

${ }^{52}$ J.G. Davies, Deacons, Deaconesses..., p. 15.

${ }^{53}$ J.G. Davies, Deacons, Deaconesses..., p. 7.

${ }^{54}$ Paul F. Bradshaw, Rites of Ordination..., p. 107.

${ }^{55}$ Paul F. Bradshaw, Rites of Ordination..., p. 49.

${ }^{56}$ D.N. Power, Ministry (Ecclesiology), in „New Catholic Encyclopedia”, $2^{\text {nd }}$ edition, 9, Thomson Gale, USA, 2003, p. 653. 
a very good way of involving the lay people in the active Church life by fulfilling the minor liturgical roles.

An important role of the minor orders was that of stepping stone. Or, in Bradshaw's words before ascending in the major order one would "serve some form of apprenticeship in lower orders" ${ }^{\prime \prime 7}$. This midway period was also a period of examination and training before engaging in more difficult tasks. This probationary period in the course of a career in ordination was called cursus honorum and was "regarded as an ascending series of steps up a single ladder" ${ }^{\prime \prime}$. The same argument is brought by Lindsay that states „it made those lower orders the recruiting ground for the higher, and in this way constructed a ladder by which deserving men could climb from the lowest to the highest ranks of service within the Church of Christ" ${ }^{\prime \prime}$. We see that this was observed both by man and women. For the men clergy, most of them started as readers, advanced in subdeacons or acolytes and afterwards in the major clergy as deacons and so on ${ }^{60}$. For a woman to become a deaconess had to be first appointed as a widow. Thus the minor orders are a period of transition: „before 1972 the minor orders had become no more than transitory stages to the priesthood" ${ }^{\prime 61}$.

An important distinction that has to be made concerning the liturgical role of the minor orders is between sacrament and sacramental. The term sacrament is reserved only to the major orders whereas the sacramental is reserved to the minor orders. The difference is made by the one who receives the laying of the hands or the ordination - in the technical sense of the term. As we saw only the major orders receive the laying of the hands whereas the minor orders receive an institution. Both the major and the minor orders have been part of the clergy but only the former are sacraments and only the latter are sacramentals. As the functions of the latter are not limited to the Liturgy they could perform many of the other duties of the clergy (e.g. the exorcist had also a very important pastoral role). We saw some of the minor orders receiving the

\footnotetext{
${ }^{57}$ Paul F. Bradshaw, Rites of Ordination..., p. 133.

${ }^{58}$ Paul F. Bradshaw, Rites of Ordination..., p. 136.

${ }^{59}$ Thomas M. Lindsay, The church and the ministry in the early centuries: the eighteenth series of the Cunningham lecture, Hodder and Stoughton, London, 1910, p. 356.

${ }^{60}$ J.G. Davies, Deacons, Deaconesses..., p. 11.

${ }^{61}$ Minor orders..., p. 1090.
} 
laying of the hands and others not. This imposition of the hands meant basically that an individual was commissioned for a particular task or ministry (Acts 13,1-3) and soon became a standard practice for ordaining the orders. During the development of the minor orders an important stage was the establishment of the term that defined the ordination of one in this category. This need appeared once the laying of the hands was extended to almost all of the minor orders. Thus, for the minor orders was used the term cheirotonia and for the minor orders epithesis. Whitham argues that the minor orders were ordained by „various ceremonies expressive of the duties which they had to perform" and that only the major orders can be called Holy Orders ${ }^{62}$.

During their development, basically the three constituent parts of every ritual of consecration of the minor orders constituted a presentation of the duties of that order, passing of the instruments proper to each order with a formula indicating the importance and the duties of that order, and a concluding prayer pleading God's blessing over the candidate. They are now conferred by a ceremony of institution and not of ordination. The one that officiates the service is the bishop or a representative of him, but it can also be done by an abbot or by a major religious superior. In 1972, the Roman-Catholic Church abolished the minor orders keeping only two of their components, acolyte and lector. This restructuration of the minor orders happened because once the disciplina arcani ceased to exist many of the minor orders lost their reason for functioning. If the need disappeared the same happened with the order. If there was no need for doorkeepers (due to the disappearance of the catechumens), exorcists, or subdeacons anymore they ceased to exist. Bradshaw commented regarding this gradual process of the minor orders that ",all regarded their development as part of God's providence" ${ }^{\prime 63}$.

\section{Conclusion}

In the Early Church we see that the minor orders were chosen by the bishop and people were only giving their consent. That leads

\footnotetext{
${ }^{62}$ A.R. Whitham, Holy Orders..., p. 277.

${ }^{63}$ Paul F. Bradshaw, Rites of Ordination..., p. 137.
} 
us to the conclusion that they were not so much in the service of the people but more in the service of their superiors. The minor orders did not have a direct liturgical role and did not fulfilled any specific role related to the celebration of the Eucharist but all their duties were related to actions that helped preparing and helping the major orders who are the only ones in charge with its celebration. We saw that the minor orders represented a stepping stone towards the major orders and a helpful way of involving the laymen in the life of the Church. Even if today in some cases we cannot find a proper ordination service of the minor orders we still find people fulfilling their roles (e.g. acolyte). Not being concerned with leadership as the major orders the minor orders had more administrative, organizational and of ministry duties. 